$\mathbb{T}$ Periodica Polytechnica Social and Management Sciences

\author{
26(1), pp. 19-29, 2018 \\ https://doi.org/10.3311/PPso.9159 \\ Creative Commons Attribution (i)
}

RESEARCH ARTICLE

\section{Ramp-up Process Improvement Practices for Time-to-Market Reduction}

\author{
Krisztián Szabó ${ }^{*}$
}

Received 10 March 2016; accepted after revision 31 May 2016

\begin{abstract}
The importance of the "Ramp-up bridge" covering the gap between product development and serial production, as well as the speed at which this bridge can be crossed, has increased, providing companies with a significant competitive advantage.

However, a significant percentage of project aiming to introduce new products do not achieve their goals. [(60 percent of the automotive supplier ramp-up projects fail on either the technical, or the economic side (Bischoff, 2007)].

The author explores the possible reasons, then makes suggestions regarding the support of successful ramp-up projects, through practical examples taken from the industry.

Through the continuous improvement of ramp-ups, a new core competency can be achieved, with a decrease in time-tomarket. This core competency is difficult to duplicate, and can provide an additional competitive advantage for companies manufacturing products with high technical complexity.
\end{abstract}

\section{Keywords}

ramp-up, time-to-market, core competency, continuous improvement, TQM, quality management, high technical complexity

\footnotetext{
${ }^{1}$ Department of Management and Corporate Economics, Faculty of Economic and Social Sciences, Budapest University of Technology and Economics, 1117 Budapest, Magyar tudósok körútja 2., Hungary

${ }^{*}$ Corresponding author, e-mail: ing.krisztian.szabo@gmail.com
}

\section{Introduction}

The effects of globalization processes have resulted in competition between companies which only a few decades ago would never have come into contact, or some which might not have even existed. The resources allocated to research and development have increased several-fold. The speed of development has also vastly increased: we need look no further than the automotive industry, where only a few decades ago developing of a new model took 5-7 years decreasing to a mere 30 months by 2008 (T-Systems, 2008). The time-to-market factor has been drastically reduced. Due to the increasing range of products and the simultaneously shortening product lifecycles, the ramp-up process become increasingly important for the success of the companies (Lanza and Fleischer, 2005; Kampker et al., 2013; Schmitt and Schmitt, 2013). This statement is especially valid for the technically complex manufacturing fields of vehicle, agriculture, forestry and construction machine production.

The importance of ramp-up becomes clear if the great impact of production ramp-up delay on the profit of a company is considered. (Lanza, 2005; Westkämper, 2003). Let us examine the individual elements of these losses by using a vehicle manufacturing example, to explore the reasons which might not be apparent at first. Two significant types of losses can be differentiated. First are the forgone sales, including losses due to the late market launch, customer migration, and reduced production capacity. Secondly, we must consider increased costs, which themselves comprise a number of different elements: increased costs of production, development, resources used for ramp-up/SOP (start of production), warranty and goodwill, as well as the cost of changes, especially late changes. What, then, would the overall total come to?

Assuming 500000 units produced annually, a product launch delay of 6 months, and a manufacturing time of 7 years, McKinsey analysts have calculated the total loss to be USD 6.465 billion. A summary of the above can be seen in Fig. 1 . Is it possible to reduce these extremely high losses, and if yes, how? Investigating this issue is the aim of this research paper.

In Section 2, the ramp-up process is positioned in the field of competitive strategies, competitive advantages, market 


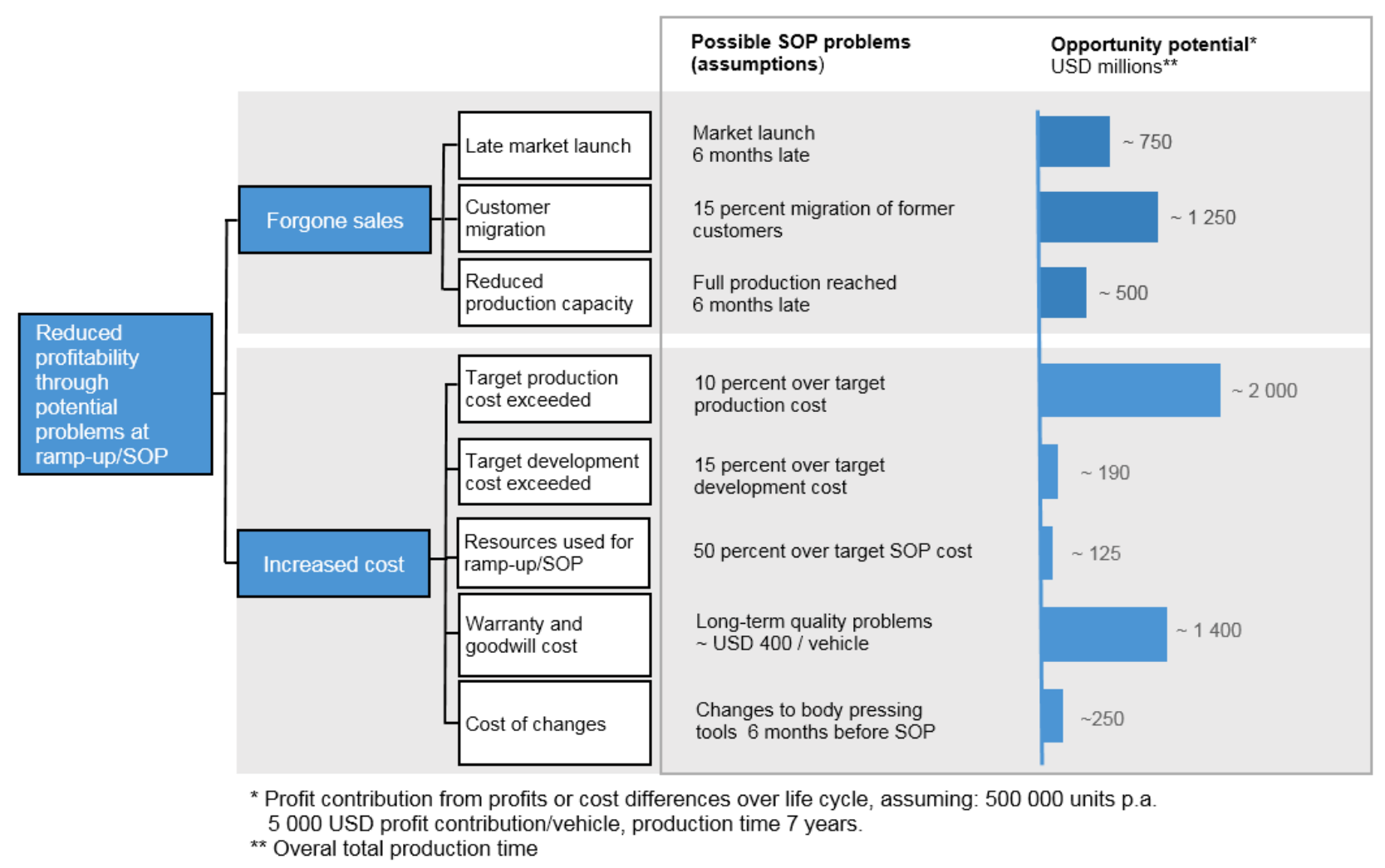

Fig. 1 Impact of maturity on profitability (McKinsey, 2002)

characteristics and required quality management systems. In Section 3, ramp-up process improvement practices will be presented, based on manufacturing experiences with products of high technical complexity. The result of the research paper, included in Section 4, will demonstrate the application of the presented process improvement practices, potentially leading to a new core competency that is difficult to duplicate. This core competency can provide an additional competitive advantage for companies manufacturing products with high technical complexity.

The researcher's long-term objective is to further develop the described ramp-up improvement processes, in order to create a flexible Total Ramp-Up (TRU) system for companies manufacturing products with high technical complexity.

\section{Competitive strategies}

A company's competitiveness is determined by both internal and external factors. The internal factors comprise the core competencies derived from the operation of the company, while the external factors are defined by external market success factors. Competitiveness is defined by how well a company can withstand competition, and is based on acquired experiences, inherited talents or acquired knowledge (Marosán, 2001).

The competitive strategy of a company can be either explicit or implicit, but in either case, it defines the operation of the company's divisions, or even the company as a whole (Porter, 1993).
Table 1 Generic strategies (Porter, 1993)

\begin{tabular}{llcc}
\hline & & \multicolumn{2}{c}{ Competitive advantage } \\
\cline { 3 - 4 } & & Lower cost & Differentation \\
\hline Competitive & Broad target & Cost leadership & Differentation \\
scope & Narrow target & \multicolumn{2}{c}{ Focus } \\
\hline
\end{tabular}

Differentiating strategies can be very diverse. The company could focus, for instance, on short delivery times, low prices, high quality, meeting specific customer needs, flexibility, custom manufacturing, a wide range of built-in options, variants, dependability and extended warranty periods, or any combination of these factors. The competitive strategy best suited for achieving a leading position in the market is always dependent on the specific market requirements, which can in turn depend on or be influenced by global political events. As an example, we may consider the types of products that would be required by the population of a country in a post-war period (today's Syria or Iraq, for instance).

During the post-World War II period, the dominant corporate strategy was to keep costs low (cost-based competition) (Stalk, 1988). Later, more focus was given to the reduction of overall costs (scale-based competition). In the 1970s, by contrast, once the major corporations had all become able to produce their products at similar costs, additional competences became necessary to achieve competitive advantage. This new type of competitive advantage was quality (quality-based competition). By the 1990s, however, the production of high-quality, low-cost 
products was also no longer sufficient for achieving competitive advantage. A new competitive factor appeared, which was time (time-based competition) (Chikán and Demeter, 2001).

Time characteristics can also be grouped, as per the following table by De Toni and Meneghetti:

Table 2 Internal and external time performances (De Toni and Meneghetti, 2000)

\begin{tabular}{llll}
\hline & \multicolumn{2}{c}{ Time performance } \\
\cline { 3 - 4 } & & Internal & External \\
\hline \multirow{4}{*}{ Phase } & & FI \\
& & & (Frequency of \\
& Product & TTM & introducing) \\
& Development & (Time-To-Market) & - new products \\
\cline { 2 - 4 } & & & - existing products \\
& & & improvements \\
\cline { 3 - 4 } & Procurement & (Lead Time) & DT \\
& Production & - procurement & (Delivery Time) \\
& Distribution & - production & - speed \\
& & - distribution & - punctuality \\
& & &
\end{tabular}

In the period of time-based competition, companies firstly attempted to reduce the direct (external) time factors which would be immediately noticeable by the customers, then moved their focus to the indirect (internal) time factors. (Kalló, 2010). Generally speaking, the time-based competition approach was first adopted by companies in the manufacturing sector, then in sales and distribution, and finally in the field of innovation (Stalk, 1988). Thus, time-based competition is also possible by improving the various time factors related to Supply Chain Management (Ji, 2008).

Naturally, the specifics of the market where the company is operating must still be taken into consideration. Management must focus the company's resources on those internal or external time factor reductions which can be perceived and appreciated by customers.

We must keep in mind that these optimization processes are never an end in themselves. At a minimum, they serve to reduce costs, which itself translates to a competitive market advantage. The relationship between market characteristics and strategies are presented in Table 3 .

Table 3 Market characteristics and strategic orientation (De Toni and Meneghetti, 2000)

\begin{tabular}{|c|c|c|c|}
\hline \multirow{3}{*}{$\begin{array}{l}\text { Market } \\
\text { sensitivity to } \\
\text { frequency of } \\
\text { introducing } \\
\text { or improving } \\
\text { products }\end{array}$} & High & $\begin{array}{l}\text { Product time-based } \\
\text { competitor } \\
\text { III. }\end{array}$ & $\begin{array}{l}\text { Product \& Process } \\
\text { time-based competitor } \\
\text { IV. }\end{array}$ \\
\hline & Low & $\begin{array}{l}\text { Design /Production } \\
\text { cost-based competitor } \\
\text { I. }\end{array}$ & $\begin{array}{l}\text { Product \& Process } \\
\text { time-based competitor } \\
\text { II. }\end{array}$ \\
\hline & & Low & High \\
\hline & & \multicolumn{2}{|c|}{$\begin{array}{l}\text { Market sensitivity to delivery time } \\
\text { (speed and punctuality) }\end{array}$} \\
\hline
\end{tabular}

As a result of recent research, we are also able to determine the quality system necessary for achieving specific fundamental objectives (see Table 4) as well as how these systems are interconnected, and how they build upon each other (Szabó and Szabó, 2014).

Table 4 Connection of quality system and fundamental objective (Szabó and Nagy, 2009)

\begin{tabular}{ll}
\hline \multicolumn{2}{c}{ Minimal required quality system } \\
\hline Fundamental objective & Required quality system \\
\hline Meet the specification & Quality control \\
Meet the function requirements & Statistical quality control \\
Meet the evident customer demands & Total quality control \\
Meet the hidden customer demands & TQM \\
Meet the environmental and society & Integrated systems \\
demands & \\
\hline
\end{tabular}

In high value added markets, which are characteristic of the automotive, agricultural machine manufacturing or electronic industries, among others, we find Segment IV to be dominant (see Table 3), meaning time-based competition on the product and process levels (the market is highly sensitive to the frequency of introducing or improving products, as well as to delivery time). These demands require the application of TQM and integrated systems (see Table 4). Table 5 shows the applicable TQM methods.

Table 5 Classical QM and new TQM methods (Szabó G. Cs., 2013)

\begin{tabular}{ll}
\hline Classical QM methods, & Comprehensive, new TQm methods \\
what partly used by TQM & \\
\hline - Error analyze methods: & - Data collection, visualization, analyze, \\
-> Pareto/ABM, & - Benchmarking, \\
-> Ishikawa & - SWOT analyze, \\
-> FMEA/FMECA & - Environment and market analyze, \\
-> TIPHIB & - Portfolio analyze, \\
- Problem solving, & - Organization analyze, \\
- QFD/QH (quality house), & - Mission, vision, \\
- Quality teams, & - Management style, \\
- List of open points, check lists, & - Company culture and development, \\
- Quality audits, & - Communication analyze, \\
- Statistical methods, & - Motivation analyze, \\
- Flowcharts, & - Conflict and risk management, \\
- Statistical process control cards,, & - Environment protection and culture, \\
- 5W+1H & - Company audit, \\
- 5S, & - Human resource analyze and \\
- 7 steps problem solving, & development, \\
- Sampling methods. & - Work safety, health, work culture, \\
& - JIT, TPM systems, \\
& - PQC, SQM, \\
& - 7M, 9M, \\
& - PDCA problem solving, \\
& lean), \\
& - Decision making process and delegation \\
& \\
&
\end{tabular}


The key to the integrated systems' success is management itself.

Research and Development, Quality Management and Production are not exclusively responsible for the successful introduction of a new product; all other management elements must also bear responsibility (see Table 6). All management areas of the company must be present in the product introduction project. The management system as a whole can never be stronger than its weakest link (Szabó, 2014a).

Table 612 elements of TQM (Szabó, 2013)

\begin{tabular}{ll}
\hline & 12 elements of TQM \\
\hline Strategy management & $\begin{array}{l}\text { Project and teamwork management } \\
\text { Accounting and Finance } \\
\text { Quality and reliability management } \\
\text { management }\end{array}$ \\
$\begin{array}{l}\text { Human Resource management } \\
\text { Research and Development }\end{array}$ & $\begin{array}{l}\text { Management of quantitative } \\
\text { management }\end{array}$ \\
$\begin{array}{l}\text { Marketing management } \\
\text { Production and technology } \\
\text { management }\end{array}$ \\
$\begin{array}{l}\text { General management culture, } \\
\text { decision system, leadership theory }\end{array}$ & Issue based problem solving \\
\hline
\end{tabular}

SWOT analyses and related programmes for the individual areas, including, for instance, Pareto based development programmes, deliver substandard results from the entire company's point of view, because departments not assigned an A category (the notation "A" referring to the class A used in Pareto-analyses) are not developed, and therefore remain weak. In the researcher's opinion, it would be beneficial to abandon the generally adopted approach of categorizing a company's internals into main and supporting processes, and stronger and weaker departments. It is more worthwhile to have a weaker but unified level of management across the whole organization than to have only one extremely strong department. Therefore, an even distribution of resources among the different management departments is vital (Szabó, 2014b).

The focus should not be exclusively on Production. The same priority should be given to Purchasing, Supply Chain Management, Quality and Human Resource Management, as well as IT. However, these decisions must always be made with a clear understanding of the organization's specific circumstances, allowing the company to grow in the fastest and most efficient way.

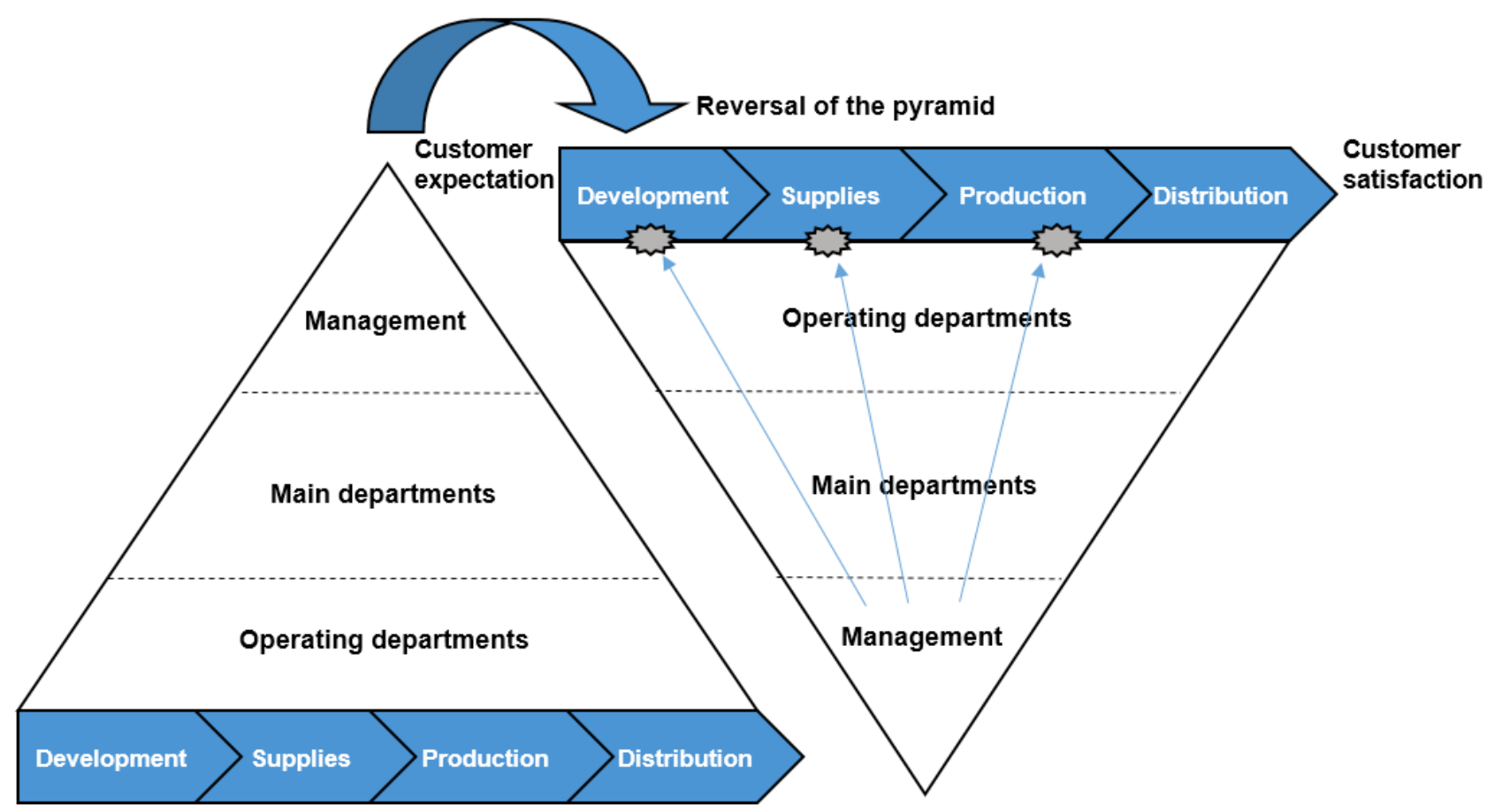

Fig. 2 Organization pyramid reserve through continuous improvement approach (Gobetto, 2014)

The speed of growth has become extremely high, according to Klaus Schwab, Founder and Executive Chairman of the World Economic Forum: "In the new world, it is not the big fish which eats the small fish, it's the fast fish which eats the slow fish." The most successful companies will be those able to respond the fastest to market demands.

This philosophy demands a much higher speed of product development and realization compared to earlier approaches.
The most challenging and most complex phase of this process is the ramp-up phase, when the project moves from prototype production to the serial production phase during product development and manufacturing (see Fig. 3) (Schuh et al., 2005).

New product introduction projects for automotive suppliers are so complex that they often fail during their ramp-up phase. 60 percent of projects cannot meet the technical and/or economical requirements (Bischoff, 2007). 


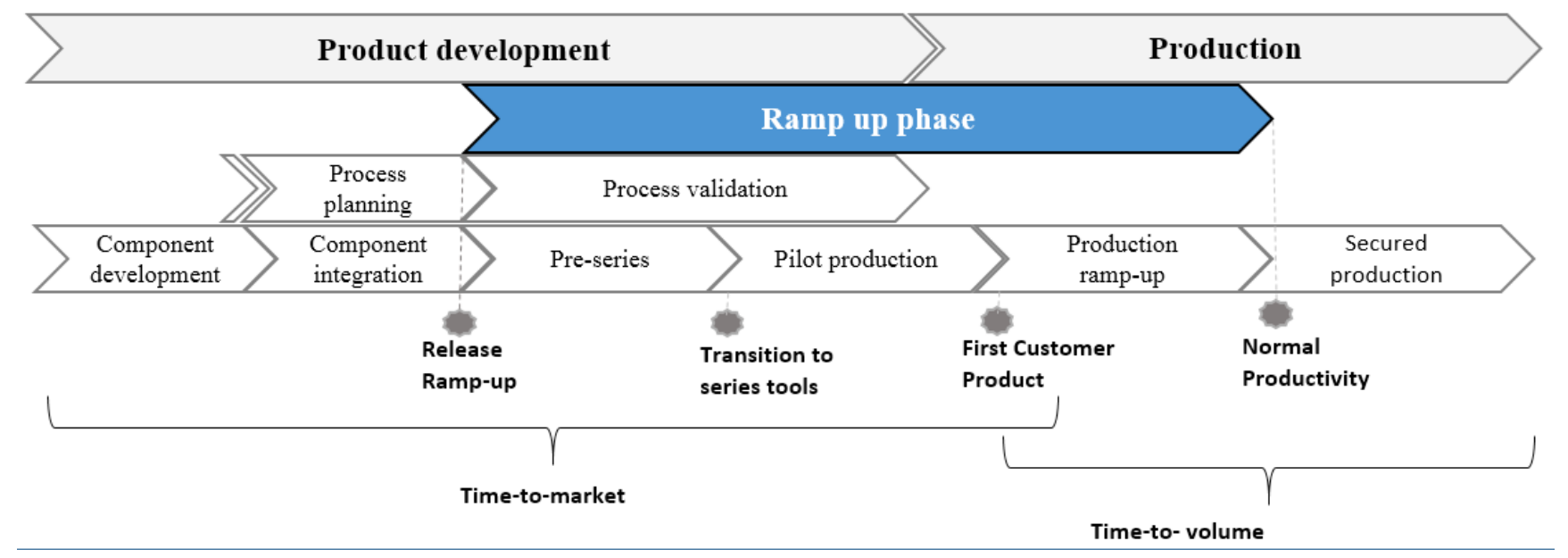

Fig. 3 Alignment of ramp-up phase in the product development process (Schuh et al., 2005)

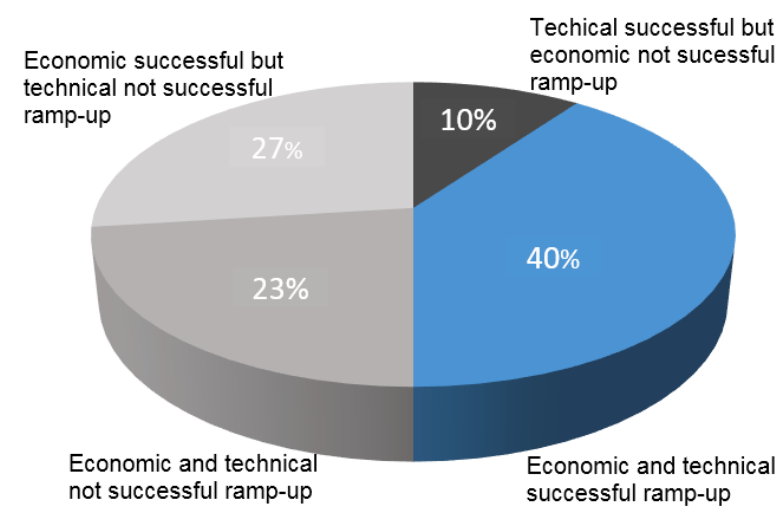

Fig. 4 Technical and economic achievement of production ramp-ups in the European automotive supplier industry (Bischoff, 2007)

What are the root causes of this phenomenon? What are the reasons behind the delays? What causes the significant discrepancies from the project targets? Are there any elements of the process which would predict an unsuccessful ramp-up phase?

\section{Critical ramp-up success factors from industrial practice}

The examples presented are based on practical experiences, and can find application in the automotive, agricultural, construction, or forestry machine manufacturing industries, which all involve the manufacturing of products with high technical complexity.

\subsection{Planning}

It is worthwhile to prepare a radar chart at the very beginning of the ramp-up project's planning. Here we are able to compare the required resources of a new product ramp-up with the required resources of an earlier, reference ramp-up. An example of a radar chart is shown in Fig. 5.

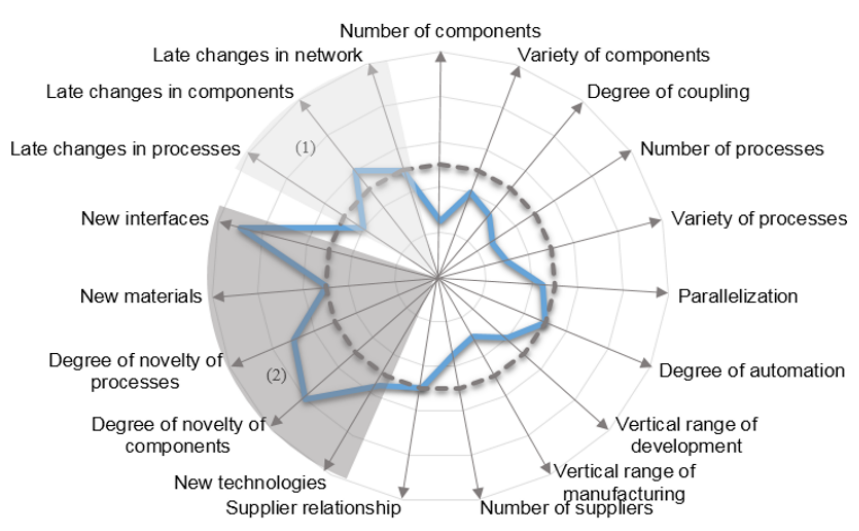

(1) Late changes

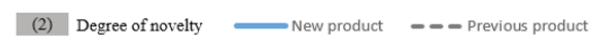

Fig. 5 Identification chart for detailed analysis (Elstner and Krause, 2014)

By inspecting the complexity identification radar chart, we can receive visual feedback about whether the provided resources will be sufficient for the new ramp-up team (compared with the resources provided to an earlier, successful rampup team). By applying this method, it becomes clear where further enhancements are necessary, and which areas require more resources. According to the author's opinion, it is particularly important to understand that we should not restrict our investigations merely to the development project and its realization phase. The project should be mapped onto the time horizon of the full corporate product development portfolio. We can call this portfolio a product road map. This road map is required for us to be able to securely provide each and every project with the required resources, and to show us the synergies between our various development projects. Moreover, with this product road map approach, we can avoid different research and development projects entering the ramp-up phase simultaneously. This is significant, because entering the ramp-up phase at the same time could dilute the resources of the production company in question, which can lead to the failure of the projects. 


\subsection{Complexity and resource allocation}

Let us pose a theoretical question: If a project team was barely able to achieve an introduction project for a product with low technical complexity, then given the same team number, composition, and work hours, will the team be able to complete a similar project for a product with high technical complexity? The answer is not known. However, presumably, a re-allocation of project resources will be required.

The key element of the ramp-up projects is their complexity. What are the main factors capable of influencing the complexity of ramp-up projects? The summary of these factors is shown in the figure below:

$\begin{array}{lll}\text { Degree of novelty } & \text { Network complexity } & \text { Process complexity } \\ \text { New technologies } & \text { Vertical range of development } & \text { Number of processes } \\ \text { New components } & \text { Vertical range of manufacture } & \text { Variety of processes } \\ \text { New processes } & \text { Number of suppliers } & \text { Coupling of processes } \\ \text { New materials } & \text { Supplier relationship } & \text { Degree of automation } \\ \text { New interfaces } & & \\ \text { Product complexity } & \text { Late changes } & \\ \text { Number of components } & \text { Late changes in processes } \\ \text { Variety of components } & \text { Late changes in components } \\ \text { Degree of coupling } & \text { Late changes in network }\end{array}$

Fig. 6 Indicators for the main infulencing factors (Elstner and Krause, 2014)

These influencing factors should be limited, reducing the complexity as much as possible. Standardization is necessary, otherwise we will be unable to achieve our original objective: bringing the new product to market as quickly as is feasible, and reducing the time-to-market factor to the greatest extent possible.

Planning should be managed with standardized raw materials, standardized technologies and standardized parts as much as is practicable. If this is not possible, then it should be investigated whether the company has previously manufactured similar components to the one in question. These previously manufactured parts could possibly be usable for the new design as well. (Some 3D modelling software tools are already capable of finding identical or similar components from the archive database, based on the geometry used, and offer these previously designed components to the designer for use.)

Our primary objective is to modify the processes for products with high technical complexity, in order to lower the technical complexity and level of resources required [design and validation time, searching for new suppliers, building up new supply chain management, testing prototypes, inventory risks, modifying and procuring manufacturing and logistics tools, full-scale processing of the parts in the enterprise resource planning (ERP) system, technical documentation management, training, education]. On the whole, the product with high technical complexity should be "pushed" towards the centre of the complexity identification radar chart (see Fig. 5) and on at lower resource level, the resource demands should be managed using standardized processes.

\subsection{Standardized processes}

Moving on from the component level, the entire product development process should be standardized and traceable. Process steps and reports should be clear and easy to understand. It should not be up to the project team to guess the $n+1$ th step of the process during the development project itself. The steps should be pre-defined, reducing recurring consultation times and the associated costs. The design scope and solution space will then be narrowed, reducing the time-to-market (see Fig. 7) which can result in a better competitive position for the company.

The development phases should be divided into milestones. At the end of each phase, a detailed milestone meeting is required, where the result of the phase is presented in a standardized milestone report form. Figure 8 below illustrates a possible new product introduction process pyramid. Naturally, the number of milestones could be increased or decreased as necessary, or even

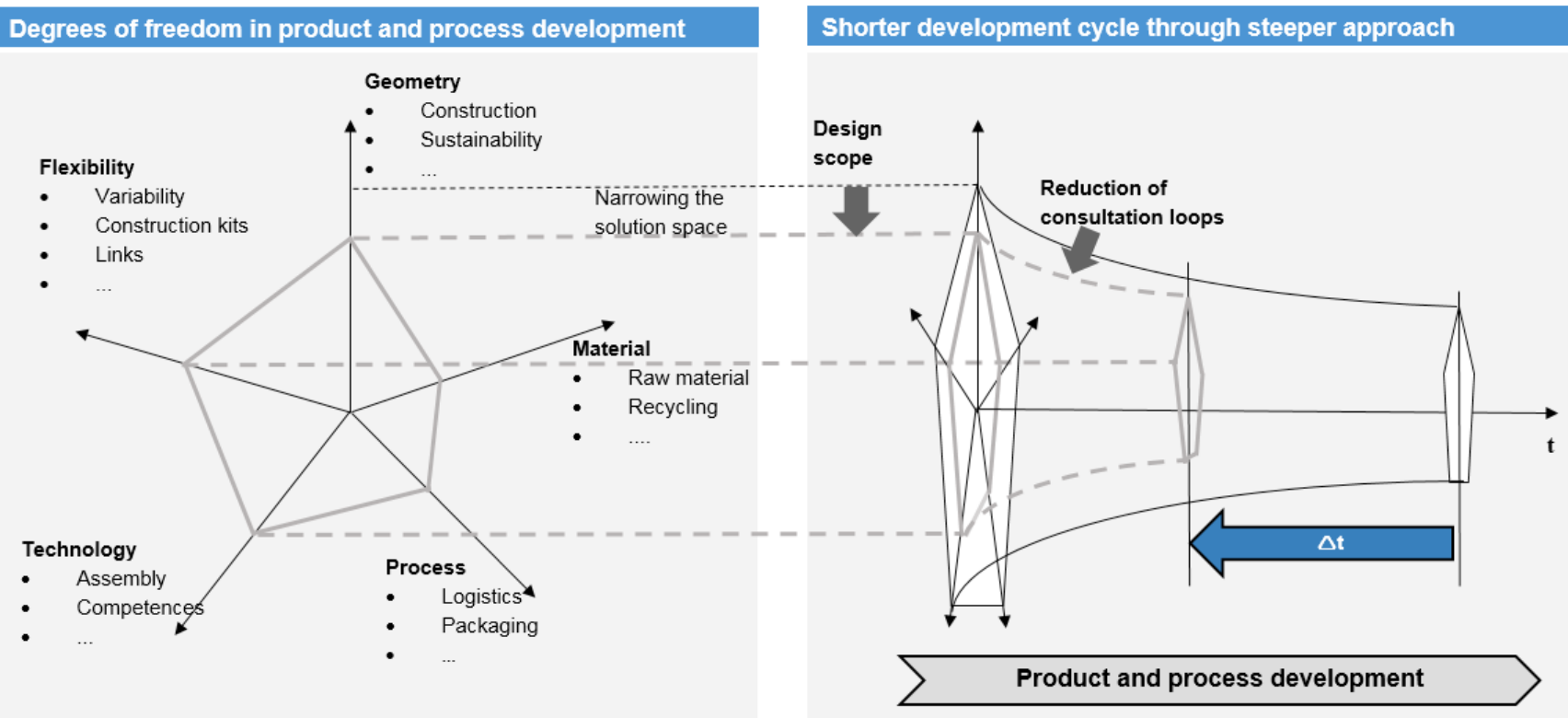

Fig. 7 Time-to-market benefits due to standardization (Kampker et al., 2014a) 


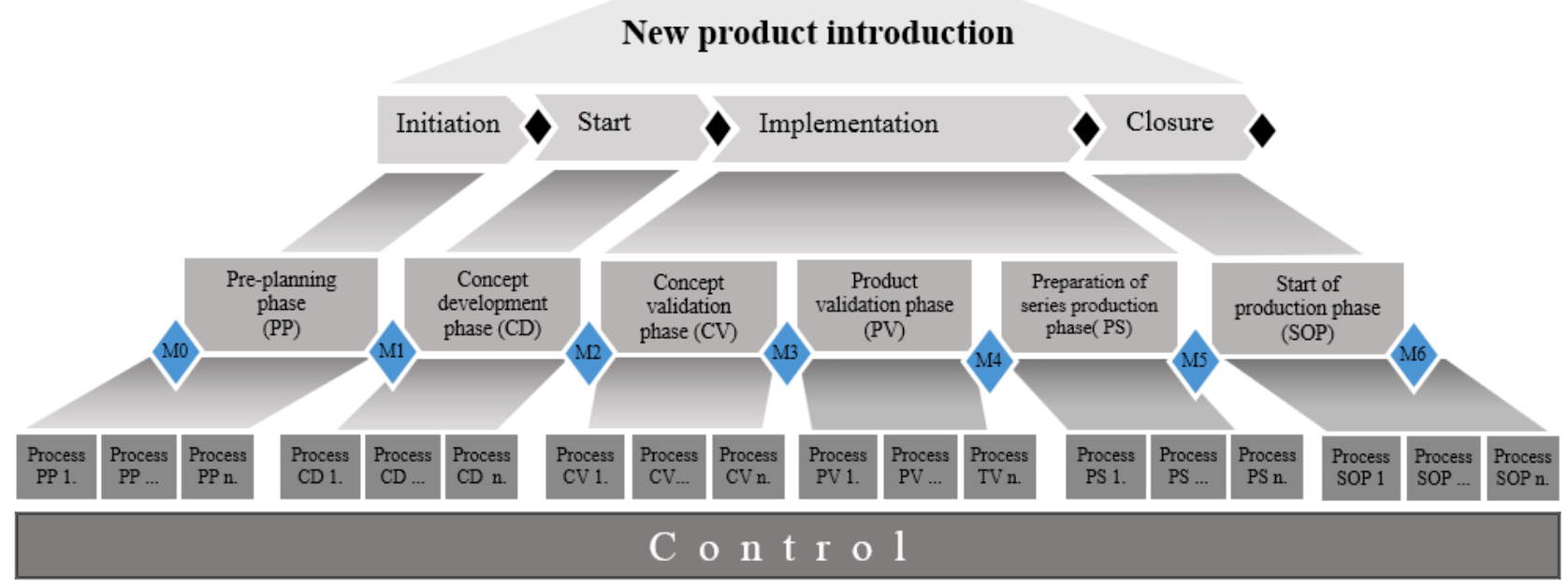

Fig. 8 New product introduction process pyramid (Own figure)

merged, depending on the complexity of the project. The content of each milestone should also be pre-defined. Every team member should be fully aware of what their task is, and what results are expected of them. The result of the project evaluation should be clear and pre-determined. (The researcher calls attention to the importance of the project members operating on the corporate project portfolio level, as opposed to the level of a single project.)

\subsection{Process evaluation}

Many companies apply the red, yellow and green traffic light criteria to evaluate the processes. This, however, is not always sufficient to indicate the actual status of the product development or the realization processes.

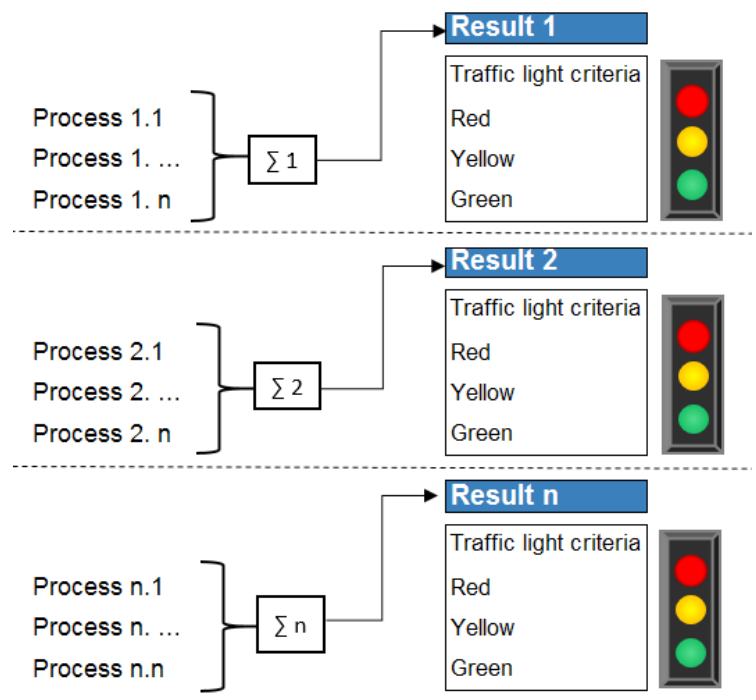

Fig. 9 Traffic lights (Own figure)

The author suggests the implementation of a numeric scale with five values, where the first stage does in fact mean that the project needs to be aborted, and the other four stages can be interpreted as follows:

\section{1 - STOP; 2 - 1-33\%; 3 - 34-66\%; 4 - 67-99\%; \\ 5 - Completed (100\%)}

It is important to define in advance, and in writing, what precisely is meant by the standard process being, for example, $1-33 \%$, or $34-66 \%$, or $67-99 \%$ complete.

The results can be weighted according to the importance of the process, as not all the processes are of equal value to the project. For instance, the importance of the manufacturing equipment not having yet been completed is not equivalent to that of some missing translations of technical drawings (into the mother tongue of the production workers). However, according to the original traffic light criteria, both processes would have been assigned the same red light. With the more precise stages, and their assigned weights, a more objective indication of the project status can be gained. Thus, the different ramp-up projects become comparable. With this approach, it is possible to avoid an overly optimistic view of the project, which could otherwise lead to significant extra costs later on.

In summary, we would be able to switch from a quasi-objective evaluation system to a fully objective evaluation system.

\subsection{Schedule and resource allocation}

The time schedule of projects are becoming ever shorter due to the high expectations set by the market. In our example, let us reduce the time allocated by $33 \%$, from 3 years to 2 years, while not altering the engineering resources or engineering work hours available. This will result in an overload in product development, which can spill over and cause delays in connected areas, such as Tool Manufacturing, Purchasing, Supply Chain Management or Human Resource Management. This can result in the necessary tools for production not being available on time, or a suboptimal selection of suppliers. For instance, the quickest suppliers will be given the opportunity to deliver the parts for the pre-series, as opposed to the optimal suppliers. This means that the structure of the supply chain will 
also not be optimal. There will be no time left for knowledge transfer, which would otherwise improve production and speed up the ramp-up process. These delays will generate additional, unplanned extra costs for the project.

It is clear that the allocation of resources is not optimal. If the realistic project time schedule plan is decreased by $33 \%$ (the time-to-market is decreased by $33 \%$ ) but all other conditions remain unchanged, the number of engineering hours should have been increased by at least $33 \%$, to prevent the occurrence of unplanned increased costs at the connected departments. A good example of an increase in unplanned extra costs would be the late completion or modification of a component, which could then incur further costs on the order of $€ 100000$ for tool modifications. In the worst-case scenario, the new tools end up having to be scrapped, as modification proves to be impossible under the circumstances.

If time-to-market is significantly reduced in the project, then resource allocation always becomes necessary as well! This step is often skipped in projects, even though investments into earlier project phases can often save the company additional later costs that would be several times greater.

Let us consider the automotive industry, where car recalls and the associated scandals are becoming increasingly common. In the United States alone, nearly 75 million vehicles were recalled in 2014, as can be seen in the chart below:

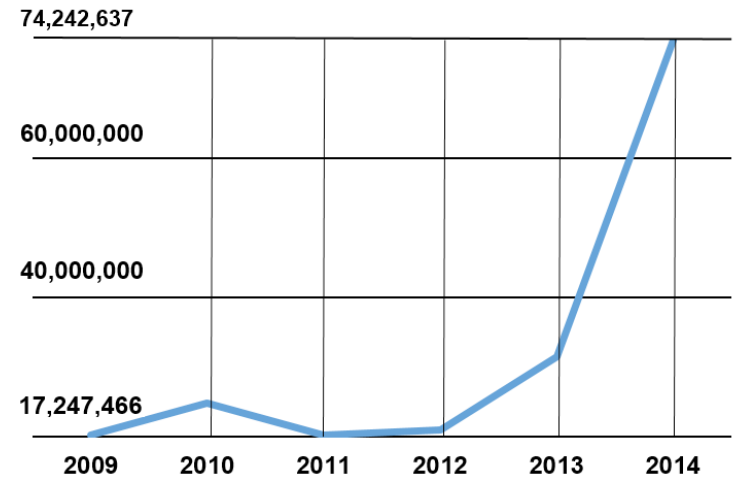

Fig. 10 Vehicle recalls in the U.S.A. (Fortune magazine, 2015)

The incidence and prevalence of errors is not equal during the various phases of product development and project realization, meaning that resources should likewise not be equally allocated!

The cost to repair 74242637 cars, using an average of $\$ 400 /$ repair (McKinsey, 2002) comes to \$29 697054800 . Using an average engineering hourly fee of $\$ 60$, this sum would have bought a total of 494950913 engineering hours. This number of hours would involve 237957.16 years of work for a single engineer, or one year for 237958 engineers (calculating with a 40-hour workweek). This number is high enough to assume that the issue could have been prevented by involving more engineers and more engineering hours. These resources should have been deployed in the M1-M2 concept development phase of the new product introduction project (see Fig. 8). The author would like to call further attention to the fact that the car recall data refers only to the United States of America. The actual number of global recalls and the related repair costs could be much higher than the above simplified calculation would suggest.

Overall, it can be stated that in the ramp-up phase, focus should be on the prevention rather than the management of errors, and in the time-to-market changes, the resource allocations should be managed proportionately, commensurately with the rate of change.

\subsection{Plan implementation into daily production, product realization}

A fundamental condition of error prevention is for each and every involved individual to have the information necessary for completing their assigned task.

Otherwise, the ramp-up projects will only move along the "actual development state" function, as opposed to converging strongly towards a stable target-development level (see Fig. 11). The researcher calls attention to the fact that the target-development level is not constant: it increases with time.

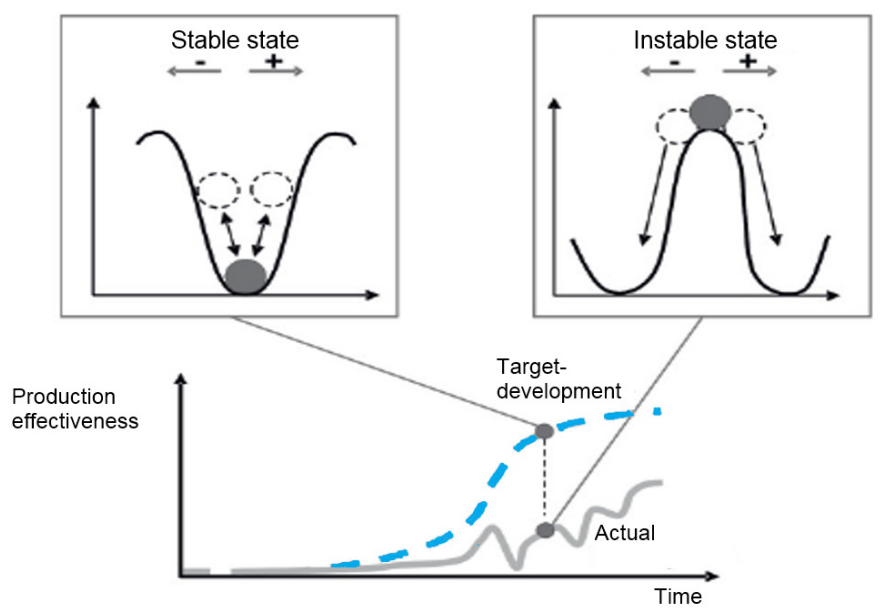

Fig. 11 Stability and instability in ramp-up (Basse et al., 2014)

As the learning curve refers to the cumulative number of product output and declines with every produced unit, the assumption that the learning curve is independent of managerial decisions suggests itself. In fact, there exist more drivers than the cumulated number, which influence the decline of the curve, i.e. the learning rate (Terwiesch and Bohn, 2001). The learning rate is shaped by the form of qualification (Kampker et al., 2014b). The level of qualification, in turn, is determined by previous experience, skills and abilities, the quality of technical education as relating to introduction of the new product, the immediate availability of education materials, and their ease of interpretation (2D, 3D assembly instructions, see Fig. 12). 


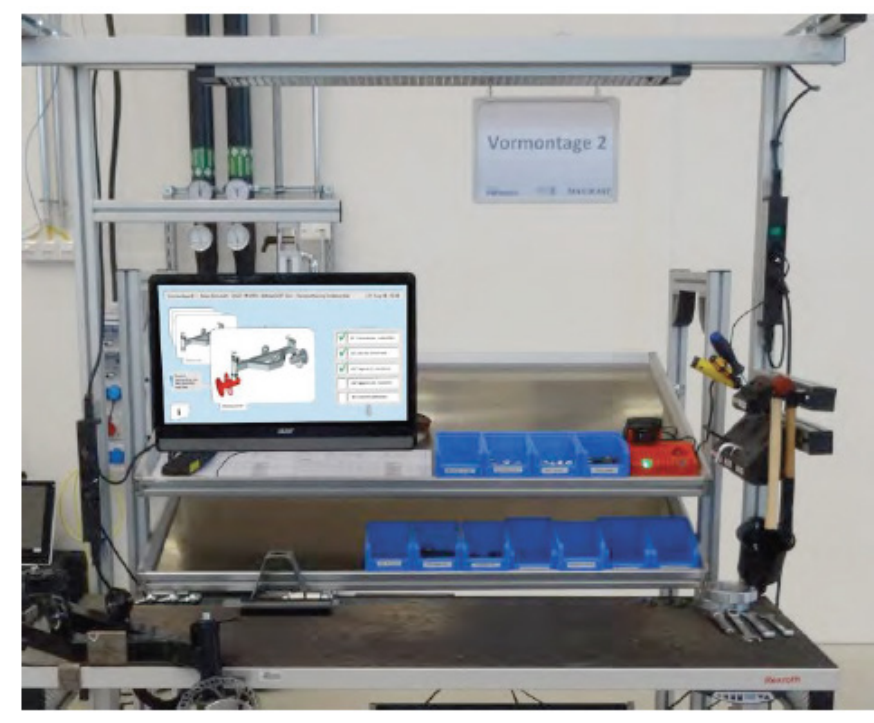

Fig. 12 Manual assembly workstation equipped with a touchscreen (Schuh et al., 2015)

On the whole, it can be stated that knowledge transfer not initiated at the appropriate time (done too early leads to forgetting, while done too late, the conversion of knowledge to skill will remain incomplete) leads to significant delays in all ramp-up projects. Therefore, the mentors (e.g. design engineers, production support engineers and/or assembly workers involved in the production of functional and/or prototype machines) have key roles in accelerating the ramp-up phase. These mentors need to be very familiar with the components and functions of the new product. At the beginning of pre-series production, during the ramp-up phase (see Fig. 3), the mentors can support the production process and the individual production steps by providing professional advice, taking part in the process either personally or virtually.

\subsection{Error management during the production}

The quality and speed of error management during the rampup phase is of high priority.

Such errors and situations calling for decision-making can arise during ramp-up, when the right expert involvement can result in an immediate decision, preventing additional costs or further significant delays. If possible, any occurring errors should be recorded digitally, as opposed to on paper, and in as detailed a form as possible. Errors can also be recorded on video (this is easily doable with modern mobile phones). The errors should be categorized, then each error should be reported to the expert responsible as soon as possible, who can then either accept the request, or forward it to a different competent expert with free capacity. When the error has been delegated to the appropriate expert, he or she will be required to give feedback about the estimated time needed for a solution to the individual recording the original error. What is vital is for all errors to be recorded and reported to the relevant experts as well as to the project manager, who then has the opportunity to respond and prepare a "lessons learned" document (Bauer et al., 2014).
It is important that a sufficient amount of expert support be available for error management, (also taking time-lag into consideration for international projects), otherwise, the lack of capacity will lead to further delays and unsolved errors, which will then become integrated into the upcoming products and processes as well.

\subsection{Ramp-up, post-production delay}

During pre-series production, it is important to ensure the necessary supply of spare parts. Missing spare parts could lead to delays and a high level of customer dissatisfaction, which can result in potential customers being turned off from the company's new product.

An overly optimistic approach should be avoided: it is important to be realistic. Additional production resources should to be planned for the ramp-up. These extra production resources will be needed to repair any technical faults in the ramp-up products. This post-production repair phase can be very time consuming, because it is likely to be performed under prototype conditions, as opposed to the production line.

\subsection{Ramp-up motivation}

During the entire ramp-up process, the motivation of workers and operators performing physical work on the production line is particularly important. If they are not sufficiently motivated, or even if the workers are penalized for errors in the new product, the time-to-market factor will be increased which is precisely the opposite of our goals.

\subsection{Learn from the mistakes, develop continuously}

After each completed ramp-up phase, the company should learn from its mistakes. Project managers should prepare lessons learned documents, and share these documents with the project team members, as well as with other ramp-up project team members working on different production sites within the group. The aim of these documents is to avoid the recurrence of the same mistakes, and continuously develop the ramp-up processes.

The importance of reducing the time factors has also been confirmed by empirical research, which show that the companies supporting the time-based competition methods are able to perform better than the ones who do not take advantage these opportunities (Kalló, 2010; Nahm et al., 2006; Vickery et al., 1995; Narasimhan and Jayaram, 1998).

\section{Conclusion}

In order to achieve the targeted production time within the ramp-up phase as soon as possible and without errors, the existing operational processes of the company must be reviewed and continuously analyzed [by applying TQM methods, among others (see Table 5)]. The ramp-up phase can be interpreted as a pressure test of the production system, as it serves to clearly identify areas requiring improvement. 
As a result of continuous ramp-up improvements, vehicle, agriculture, forestry and construction machine manufacturers have the potential to achieve a flexible but standardized production system, able to manage products of high technical complexity with a large number of variants. These companies will not only significantly reduce time-to-market, but they will simultaneously greatly improve their own operations. New core competency will be achieved which is difficult to duplicate, and provide further competitive advantage for the company. Losses due to late market launches, customer migration, or higher production costs can be mitigated (see Table 1). The production system will improve, while the net present value, project returns, and customer satisfaction will all increase.

Additional research is planned to further develop the improvement processes listed above, in order to create a flexible Total Ramp-Up (TRU) system for the manufacturers of products with high technical complexity.

\section{References}

Basse, I., Schmitt, S., Gartzen, T., Schmitt, R. (2014). Solution Principles for Managing Instabilities in Ramp-Up. In: 2nd International Conference on Ramp-Up Management. ICRM2014, Aachen, Germany, June 12-13, 2014, pp. 93-97. https://doi.org/10.1016/j.procir.2014.03.154

Bauer, W., Ganschar, O., Pokorni, B., Schlund, S. (2014). Concept of Failures Management Assistance System for the Reaction on Unforseeable Events during Ramp-Up. In: 8th International Conference on Digital Enterprise Technology - Disruptive Innovation in Manufacturing Engineering towards the 4th Industrial Revolution. DET2014, Stuttgart, Germany, March 25-28, 2014, pp. 420-425. https://doi.org/10.1016/j.procir.2014.10.058

Bischoff, R. (2007). Anlaufmanagement. Schnittstelle zwischen Projekt und Serie. 1. Auflage. Konstanz Konstanzer Managementschriften, Kontanz. (in German) URL: http://opus.htwg-konstanz.de/files/76/ Anlaufmanagement_e_book_070301.pdf

Chew, J. (2015). Here's why Toyota just recalled 6.5 million cars. Fortune magazine. URL: http://fortune.com/2015/10/21/toyota-recall-window6-million/

Chikán, A., Demeter, K. (2001). Az értékteremtő folyamatok menedzsmentje. (Management of value creation processes.) Aula, Budapest. (in Hungarian)

De Toni, A., Meneghetti, A. (2000). Traditional and Innovative Paths towards Time-Based Competition. International Journal of Production Economics. 66, pp. 255-268. https://doi.org/10.1016/S0925-5273(99)00140-1

Elstner, S., Krause, D. (2014). Methodical approach for consideration of rampup risks in the product development of complex products. In: 2nd International Conference on Ramp-Up Management. ICRM2014, Aachen, Germany, June 12-13, pp. 20-25. https://doi.org/10.1016/j.procir.2014.05.027

Gobetto, M. (2014). Operations Management in Automotive Industries. Springer. p. 199. https://doi.org/10.1007/978-94-007-7593-0

Ji, G. (2008). Service Value Delivery System Based on Time-Based Competition. In: International Conference on Service Systems and Service Management. Melbourne, Australia, June 30-July 2, 2008, pp. 64-70. https://doi.org/10.1109/ICSSSM.2008.4598521

Kalló, N. (2010). Az időalapú versenyzés támogatása a termelésmenedzsment eszközeivel. A sorképzési szabályok szolgáltató rendszerekben történő alkalmazásának elméleti megalapozása. (Supporting of time-based competition with production management methods. Theoretical foundation of application's row creation rules in service systems) $\mathrm{PhD}$ Theis, Bu- dapest University of Technology and Economics, (in Hungarian) URL: http:/hdl.handle.net/10890/923

Kampker, A., Burggräf, P., Deutskens, C., Maue, A., Förstmann, R. (2014a). Integrated Product and Process development: Modular Production Architectures Based on Process Requirements. In: 2nd International Conference on Ramp-Up Management. ICRM2014, Aachen, Germany, June 12-13, 2014, pp. 109-114. https://doi.org/10.1016/j.procir.2014.05.039

Kampker, A., Deutskens, C., Deutschmann, K., Maue, A., Haunreiter, A. (2014b). Increasing Ramp-Up Performance By Implementing the Gamification Approach. In: 2nd International Conference on Ramp-Up Management. ICRM2014, Aachen, Germany, June 12-13, 2014, pp. 74-80. https://doi.org/10.1016/j.procir.2014.05.034

Kampker, A., Gartzen, T., Voet, H. (2013). Komplexitätsorientiertes Anlaufmanagement: Entwicklung einer softwarebasierten Methodik für das Anlaufmanagement in der Kleinserie. Werkstattstechnik online. 103 (4), pp. 299 304. (in German) URL: http://publications.rwth-aachen.de/record/234490

Lanza, G. (2005). Simulationsbasierte Anlaufunterstützung auf Basis der Qualitätsfähigkeiten von Produktionsprozessen, Wbk, Inst. für Produktionstechnik, Karlsruhe. (in German)

Lanza, G., Fleischer, J. (2005). OEE-Prognose im Produktionsanlauf: Simulationsbasierte Anlaufunter-stützung mittels Kennzahlen. Werkstattstechnik online. 95(7/8), pp. 554-558. (in German) URL: http://www.werkstattstechnik.de/wt/article.php?data $\% 5$ Barticle_i d $\% 5 \mathrm{D}=2371$

Marosán, Gy. (2001). Stratégiai menedzsment. (Strategy management.) Müszaki Könyvkiadó, Budapest. (in Hungarian)

McKinsey (2002). Product Development in the Automotive Industry - Strategies to Circumvent the Complexity Challenge. T-systems White paper URL: http://www.t-systems.com.my/umn/uti/143582_1/blobBinary/ WhitePaper_RampUp-Management-ps.pdf?ts_layoutId=636412

Nahm, A. Y., Vonderembse, M. A., Rao, S. S., Ragu-Nathan, T. S. (2006). Time-Based Manufacturing Improves Business Performance - Results from a Survey. International Journal of Production Economics. 101, pp. 213-229. https://doi.org/10.1016/j.ijpe.2005.01.004

Narasimhan, R., Jayaram, J. (1998). An Empirical Investigation of the Antecedents and Consequences of Manufacturing Goal Achievement in North American, European, and Pan Pacific Firms. Journal of Operations Management. 16(2-3), pp. 159-176. https://doi.org/10.1016/S0272-6963(97)00036-3

Porter, M. E. (1993). Versenystratégia. (Competition strategy.) Akadémiai Kiadó, Budapest. (in Hungarian)

Schmitt, S., Schmitt, R. (2013). Lifecycle Oriented Ramp-Up - Conception of a Quality-Oriented Process Model. In: 20th CIRP International Conference on Life Cycle Engineering. CIRP2013, Singapore, Apr. 17-19, 2013, pp. 441-445. https://doi.org/10.1007/978-981-4451-48-2_72

Schuh, G., Gartzen, T., Rodehauser, T., Mark, A. (2015). Promoting workbased learning through Industry 4.0. In: The 5th Conference on Learning Factories. Bochum, Germany, July 7-8, 2015, pp 82-87. https://doi.org/10.1016/j.procir.2015.02.213

Schuh, G., Kampker, A., Franzkoch, B. (2005). Anlaufmanagement: Kosten senken - Anlaufzeit verkürzen - Qualität sichern. Werkstattstechnik online Vol. 5, pp. 405-409. (in German) URL: http://www.werkstattstechnik.de/wt/article.php?data\%5Barticle_i d $\% 5 \mathrm{D}=2313$

Stalk, G. Jr. (1988). Time - The Next Source of Competitive Advantage. Harvard Business Review. 66(July-August), pp. 41-51. URL: https://hbr. org/1988/07/time-the-next-source-of-competitive-advantage

Szabó, G. Cs. (2013). A TQM alkalmazása. (The application of TQM.) Oktatási segédanyag a Kereskedelem és marketing alapszak TQM szakirány hallgatói részére. Wekerle Sándor Üzleti Főiskola, Budapest. (in Hungarian)

Szabó, G. Cs., Nagy, J. B. (2009). Új irányok, lehetőségek és módszerek a minőségmenedzsmentben. (New directions, possibilities and methods in quality management). Vezetéstudomány. 40, pp. 98-104. (in Hungarian) 
Szabó, Cs. G., Szabó K. (2014). A taylori minőség 102 éve. (102 years of Taylor quality.) Taylor Gazdálkodás- és szervezéstudományi folyóirat. A Virtuális Intézet Közép-Európa Kutatására Közleményei. 6(1-2), pp. $147-$ 156. (in Hungarian) URL: http://vikek.hu/wp-content/uploads/2015/04/ VIKEK_No14_15_nyomdai.pdf

Szabó, K. (2014a). The guarantee of quality is the quality of management. In: 5th ESD Economic and Social Development International Scientific Conference. 5th ESD, Belgrade, Serbia, 10-11 April, 2014, pp. 490-500. URL: http://www.esd-conference.com/book_of_proceedings_Belgrade_ 2014.pdf

Szabó, K. (2014b). How can we spread the quality virus in domestic organizations? Analecta Technica Szegedinensia - Review of Faculty of Engineering. 8(2), pp. 34-44. URL: http://www.analecta.hu/index.php/ issues/20142/29-how-can-we-spread-the-quality-virus-in-domesticorganizations
Terwiesch, C., Bohn, R. (2001). Learning and process improvement during production ramp-up. International Journal of Production Economics. 70(1), pp. 1-19. https://doi.org/10.1016/S0925-5273(00)00045-1

T-Systems (2008). Ramp-Up management - Accomplishing full production volume in-time, in-quality and in-cost. T-systems White paper. URL: http://www.t-systems.com.my/umn/uti/143582_1/blobBinary/WhitePaper_RampUp-Management-ps.pdf?ts_layoutId $=636412$

Vickery, S. K., Droge, C., Yeomans, J. M., Markland, R. E. (1995). Time-based competition in the furniture industry: an empirical study. Production and Inventory Management Journal. 36(4), pp. 14-21.

Westkämper, E. (2003). Assembly and Disassembly Processes in Product Life Cycle Perspectives. CIRP Annals - Manufacturing Technology. 52(2), pp. 579-588. https://doi.org/10.1016/S0007-8506(07)60205-4 